\title{
Koncesje w prawie geologicznym i górniczym
}

\section{Concessions in geological and mining law}

\author{
dr hab. Ewa Przeszio \\ E-mail: eprzeszlo@wp.pl; nr ORCID: 0000-0002-9649-4134
}

\section{dr Hanna Wolska}

E-mail: hanna.wolska@prawo.ug.edu.pl; nr ORCID: 0000-0002-9806-6336

\begin{abstract}
Streszczenie
Granice dopuszczalnej ingerencji państwa w obszarze działalności gospodarczej związanej z gospodarowaniem kopalinami wyznacza klauzula ważnego interesu publicznego. Klauzula ta koresponduje z prawną konstrukcją koncesji opartej na uznaniowym charakterze decyzji administracyjnej, co umożliwia organowi koncesyjnemu wzięcie pod uwagę wszelkich aspektów, jakie składają się na rozumienie tego pojęcia w kontekście gospodarowania kopalinami. Jednocześnie należy uwzględnić fakt, że ważny interes publiczny jest kategorią niedookreśloną i wymagającą rozważnego podejścia $\mathrm{w}$ interpretacji, przy uwzględnieniu interesów różnych podmiotów $\mathrm{z}$ punktu widzenia potrzeb ogółu. Niniejszy artykuł nie tylko wskazuje na istotę koncesji jako jednej z form reglamentacji działalności gospodarczej, ale również przedstawia specyfikę koncesji w prawie geologicznym i górniczym.
\end{abstract}

Słowa kluczowe: koncesje, reglamentacje, kopaliny, ważny interes publiczny

\section{Summary}

The extent of the state's interference with the freedom of economic activity in the filed of natural resource management is regulated by the Important Public Interest Clause. The Clause corresponds with the legal structure of a concession based on the discretionary nature of an administrative decision. Therefore, the concession authority is able to consider all relevant aspects when deciding on this matter within the field of natural resource management. However, the term "Important Public Interest" is vague and requires careful interpretation taking into account interests of various entities and having the public interest in mind. This article discusses a concession as a mean of state control over the economic activity and describes concessions in geological and mining law.

Key words: concession, state control, natural resources, important public interest

Str. 33-39

\section{Bibliografia}

Bachowski, C. (2014). Pozyskiwanie koncesji na wydobywanie kopalin pod rządami nowej ustawy Prawo geologiczne i górnicze. Przegląd Górni- czy, (8), 11-16.

Bąkowski, T. (2015). Koncesja. W: A. Powałowski (red.), Leksykon prawa gospodarczego publicznego. 100 podstawowych pojęć. Warszawa: C.H. Beck.

Ciechanowicz-McLean, J. (2012). Prawnośrodowiskowe uwarunkowania wydobywania gazu łupkowego w Polsce. Gdańskie Studia Prawnicze (28), 83-98.

Dyrektywa Parlamentu Europejskiego i Rady nr 2014/23/UE z 26.02.2014 r. w sprawie udzielania koncesji (Dz.Urz. UE L 94, s. 1, ze zm.)

Iserzon, E. (1970). W: E. Iserzon, J. Starościak, Kodeks postępowania administracyjnego. Komentarz, teksty, wzory i formularze. Warszawa: Wydawnictwo Prawnicze.

Kiczka, K. (2013). O praktyce ograniczania wolności działalności gospodarczej. W: J. Grabowski (red.), K. Pokryszka (red.), K. Hołda-Wydrzyńska (red.), 25 lat fundamentów wolności działalności gospodarczej. Tendencje rozwojowe (313-329). Katowice: Górnośląska Wyższa Szkoła Handlowa.

Klimek, G. (2016). Znaczenie i rola koncesji w ustawie — Prawo geologiczne i górnicze. W: B. Rakoczy (red.), Wybrane problemy 
prawa geologicz- nego i górniczego. Warszawa: Wolters Kluwer.

Kocowski, T. (2013). W: J. Grabowski (red.), L. Kieres (red.), A. Walaszek-Pyzioł (red.), System Prawa Administracyjnego (t. 8A). Publiczne prawo gospodarcze. Warszawa: C.H. Beck.

Kosikowski, C. (1996). Koncesje w prawie polskim. Kraków: IPSiIZ.

Kosikowski, C. (2002). Koncesje i zezwolenia na działalność gospodarczą. Warszawa: Lexis Nexis.

Lipiński, A. (2017). Cofnięcie koncesji w prawie geologicznym i górniczym. Zeszyty Naukowe Instytutu Gospodarki Surowcami Mineralnymi i Energia PAN, (100), 141-156.

Lipiński, A. (2004). Prawne podstawy ochrony środowiska. Kraków: Zakamycze.

Mikosz, R. (2008). Koncesja na wydobywanie kopalin jako prawny instrument ochrony środowiska. Gospodarka Surowcami Mineralnymi, 24(2/4), 9-25.

Nawrot, J. (2015). Interes publiczny. W: A. Powałowski (red.), Leksykon prawa gospodarczego publicznego. 100 podstawowych pojęć, Warszawa: C.H. Beck.

Nieć, M., Radwanek-Bąk, B. (2014). Ochrona i racjonalne wykorzystywanie złóż kopalin. Kraków: Wydawnictwo IGSMiE.

Popowska, B. (2016). Kwalifikacja prawna umowy koncesji. Instrument „mieszany” czy typowy dla realizacji zadań gospodarczych przez administrację publiczną? W: A. Powałowski (red.). Prawne instrumenty oddziaływania na gospodarkę. Warszawa: C.H. Beck.

Powałowski, A. (2009). Ustawa o swobodzie działalności gospodarczej. Komentarz. Warszawa: Wolters Kluwer.

Stefanowicz, J. A. (2011). Koncesje i użytkowanie górnicze w nowym prawie geologicznym i górniczym. Zeszyty Naukowe Instytutu Gospodarki Surowcami Mineralnymi i Energia PAN, (81), 5-29.

Strzyczkowski, K. (2009). Prawo gospodarcze publiczne, Warszawa: Lexis Nexis.

Szydło, M. (2004). Koncepcja koncesji w ujęciu klasycznym i jej recepcja w prawie polskim. Państwo i Prawo (1), 46-56.

Szydło, W. (2014). Zakres władzy dyskrecjonalnej i współdziałania organów samorządu terytorialnego przy udzielaniu koncesji geologicznych i górniczych. Samorząd Terytorialny, (11), 45-60.

\section{Akty prawne}

Ustawa z 14.06.1960 r. — Kodeks postępowania administracyjnego (Dz.U. z 2018 r. poz. 2096 ze zm.).

Ustawa z 30.08.2002 r. - Prawo o postępowaniu przed sądami administracyjnymi (Dz.U. z 2018 r. poz. 1302 ze zm.).

Ustawa z 29.01.2004 r. — Prawo zamówień publicznych (Dz.U. z 2018 r. poz. 1986 ze zm.).

Ustawa z 9.06.2011 r. — Prawo geologiczne i górnicze (Dz.U. z 2019 r. poz. 868 ze zm.).

Ustawa z 21.10.2016 r. o umowie koncesji na roboty budowlane lub usługi (Dz.U. poz. 1920 ze zm.).

Ustawa z 6.03.2018 r. — Prawo przedsiębiorców (Dz.U. poz. 646 ze zm.).

Waligórski, M. (2009). Koncesje na działalność gospodarczą w prawie polskim. Poznań: Wydawnictwo Forum Naukowe.

Wolska, H. (2018). Realizacja zadań publicznych przez spółkę komunalną w systemie zamówień publicznych. Warszawa: C.H. Beck. 